\title{
THE EFFECTIVENESS OF THE PROBLEM-BASED LEARNING MODEL USING PEER ASSESSMENT IN VOCATIONAL HIGH SCHOOL
}

\author{
Aulia Anggraini $^{1}{ }^{*}$, Sudiyanto $^{1}$, Cicilia Dyah Sulistyaningrum Indrawati ${ }^{1}$ \\ ${ }^{1}$ Universitas Sebelas Maret \\ Jl. Ir. Sutami 36 A, Surakarta (Solo) 57126, Indonesia
}

\begin{abstract}
This study aimed to determine the effectiveness of the effect between the Problem-Based Learning model using Peer assessment and the Problem-Based Learning model on student competencies. The study used a quantitative experimental approach at SMK Negeri 1 Sragen in class XI AK 4 as a control class and XI AK 5 as an experimental class. The population involved all XI Accounting class students totaling 160 students, while the sample consisted of 64 students divided into the experimental class and the control class. The results showed that the first hypothesis obtained Fcount data> Ftable or 5.214> 2.760 and sig values. $0.026<0.05$, then Ho is rejected, and Ha is accepted. Learning using the Problem-Based Learning model with Peer Assessment has an average value of 83.78, higher than the average value of the Problem-Based Learning model that is equal to 81.53. This study concludes that there are differences in the effect between the control class and the experimental class on student competence. The experimental class using the ProblemBased Learning Model using Peer Assessment is more effective than the control class using the Problem-Based Learning model.
\end{abstract}

Keywords: problem-based learning, peer assessment, student's competence

How to cite: Anggraini, A., Sudiyanto, S., \& Indrawati, C. (2020). The effectiveness of the problem-based learning model using peer assessment in vocational high school. Jurnal Pendidikan Vokasi, 10(2), 159-166. doi:https://doi.org/10.21831/jpv.v10i2.30956

*Corresponding Author: Aulia Anggraini anggrainiaulia19@gmail.com

- Department of Economics Education, Graduate School, Universitas Sebelas Maret Jl. Ir. Sutami 36 A, Surakarta (Solo) 57126, Indonesia 


\section{INTRODUCTION}

Learning is a teacher and student activity that is designed to help develop the potential of students into expected competencies. Various attempts have been made by the government in creating learning innovations. Learning innovations carried out usually pay attention to three important reasons, namely effective learning, efficient learning and convenience. Effective learning is learning that is able to bring students to achieve the desired learning goals or competencies. Efficient learning is a learning activity that takes place using relatively little time and resources but produces results that are beneficial to students, while convenience is a source of learning, learning media, and methods that are determined in such a way as to provide a passion for teaching for teachers and students (Pribadi, 2011, p. 15).

Effective and quality learning is when interactions between teachers and students in a learning environment are able to produce changes in student competence. Pribadi $(2011$, p. 1) argues that to be able to facilitate students in achieving the desired competencies, teachers need to master the ability to design, implement, and evaluate learning so as to create effective, efficient, and interesting learning. Daryanto and Rahardjo $(2012$, p. 2) revealed that to be able to create conditions for effective teaching and learning, there needs to be changes in classroom management, use of learning methods, teaching and learning strategies, class organizing, and actively involving students. In an effective learning process requires students to be actively involved in teaching and learning activities so as to improve student competency.

Student competence is also influenced by several components in the learning process such as objectives, learning materials, teaching and learning activities, methods, tools, teaching resources, and evaluation (Djamarah, 2005). Objectives are what will be achieved in learning activities. Clear learning objectives will make it easier for students to improve their competency. Learning material is the content or material that will be studied by students. Well organized material will make it easier for students to achieve learning goals. Teaching and learning activities are the core activities in education.

Teaching and learning activities that are running well can produce changes in competence. The method is a method used in learning tailored to the purpose. Tools are all things that can be used in order to achieve learning objectives. The source of teaching is everything that is used in the learning process that is tailored to the objectives, while evaluation is an activity carried out to obtain data about the extent of student success and teacher success in teaching. Proper evaluation will provide information to correct deficiencies so as to improve student competency.

Based on observations at SMK Negeri 1 Sragen, low student competency is possible because the learning process still ignores several learning components, including subject matter that has not been well organized, learning methods are not appropriate and the teacher has not done the evaluation of learning that supports students to learn better. Instead, the learning is centered on the teacher (teacher center) and positions students as objects. As a result, learning is only dominated by teacher lecture activities that is like one-way communication and students tend to be less active in learning.

The learning process that occurs in the field in fact, does not describe an effective learning process that does not involve students actively in teaching and learning activities. The results of interviews with tax administration subject teachers obtained some information related to the implementation of learning. These include: (1) as many as $47 \%$ of students when learning are not actively listening to lectures, taking notes and paying attention to the material provided by the teacher, (2) as many as $62.5 \%$ students are less participating in the learning process, this is marked by more students passive, students do not dare bring up questions and the lack of opportunity or a forum for discussion, (3) the student lacked discipline during the lesson, some students talking, joking with friends and other activities that have nothing to do with learning, observation results show students are less discipline of $67.5 \%$, (4) the average value of student skills seen from the results of the student worksheet for tax administration material is 60.4, and (5) the assessment is only done by the teacher at the end of the material (the teacher calls it a daily test) before proceeding to the next material without any feedback to students.

Learning components that have not been implemented effectively lead to a low level of student understanding of tax administration subjects. Lack of opportunities for students to communi- 
161 - Aulia Anggraini, Sudiyanto, \& Cicilia Dyah Sulistyaningrum Indrawati

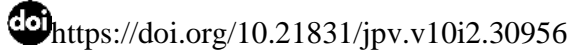

cate with teachers and fellow students, construct and explore their thoughts in the form of asking questions or giving opinions, can make students less optimal in understanding subject matter. The use of lecture method causes boredom for students, especially in learning tax administration in class XI Accounting at SMK Negeri 1 Sragen so that students become less focused. If allowed to continue it will ultimately result in low student competency. The low competence of students will have some impact students will find it difficult to continue on the next learning. In addition, students will have difficulty solving problems that exist in everyday life.

One effort to improve student competency is to use innovative learning models. One learning model that can be used by teachers and provides opportunities for students to be able to communicate more and can encourage students to think and be active is the Problem-Based Learning model. The problem-based learning model is a learning model that is carried out with the provision of stimuli in the form of problems, which are then carried out problem solving by students, which are expected to increase student competence in the achievement of learning material.

The application of the Problem-Based Learning model requires students to be able to think critically, analytically, and correctly in identifying, understanding, and solving problems, so students can apply learning material to the problems that exist in the surrounding environment. Based on research by Yew and Goh (2016), Hadie and Yusoff (2016), and Wulandari and Surjono (2013), the Problem-Based Learning model affects student learning outcomes and competencies. The Problem-Based Learning process requires a structured and systematic approach; therefore, students are encouraged to be able to present problems systematically. The application of this model can encourage students to be able to solve problems, thereby increasing students' skills in applying the concept of learning material.

Low student competency may also be influenced by the lack of evaluation in the learning process. Evaluation was preceded by an assessment. During the learning process, especially in formative tests, teachers do not give feedback to students which is useful for knowing students' abilities or providing motivation to students. Thus, the Problem-Based Learning model needs to be modified so that the learning component can be fully implemented.

Assessment is the process of obtaining information that can be used as a basis for decision making about students. Budiyono (2011, p. 58) states that assessment that is often done by teachers in Indonesia is a summative assessment that is used to get a score or student achievement without the effort to improve learning. Assessment that can be used to improve the quality of learning is formative assessment.

Peer assessment is an assessment by students of other students, in a formative assessment for feedback and scoring. Peer evaluation involves students assessing and/or providing feedback on their peers' work. Peer assessment includes a process that asks students to provide feedback based on predetermined success criteria.

Peer assessment is one form of innovative assessment that aims to empower students during the learning process and improve the quality of tax administration learning. Tax administration subjects in vocational schools embed many concepts and calculations. Students 'backgrounds have different abilities so that students' competencies also vary. The teacher is required to be able to deliver the material so that each student can master the material provided.

In addition to using the problem-based learning model the teacher can also use the assessment in the learning process. By applying models and assessments that can be used to improve the quality of learning so that students' competencies will increase. The use of the problem-based learning model using peer assessment has the advantage that students can develop new knowledge, students better understand the content of learning, and students can provide feedback on the learning process.

Based on the opinion of some experts problem-based learning model is a learning model that is carried out with the provision of stimuli to identify learning concepts that need to be known by students in the form of problems which then do problem solving by students, which are expected to increase student competence in achieving learning material.

The peer assessment also provides information about oneself and peers that may not be in accordance with what the teacher feels (Alias et al., 2015; Özbıçakçı et al., 2012; Yew \& Goh, 2016). Falchikov in Thomas et al. (2011, p. 3) says that peer assessment includes processes that require 
students to give feedback on the learning process, assign values to results, processes and performance based on success criteria where students may also be involved in determining learning criteria.

Problem-based learning is not designed to help teachers provide as much information as possible to students, but problem-based learning is developed for students so that they can develop thinking abilities, problem solving, and student competencies. The application of the combination of Problem-Based Learning models can encourage students to think more critically and more precisely in understanding and applying learning material, then it is combined with peer assessment which helps students to provide feedback in the learning process.

\section{RESEARCH METHOD}

In this study, the research design used is factorial design because the information provided by an experiment can be significantly improved by emphasizing the simultaneous effect of two or more independent variables on the dependent variable and also the interaction between some of these variables. This study uses a $2 \times 2$ simple factorial design to determine the effect of two independent variables on the dependent variable. Data obtained in the study will be processed by conducting a hypothesis test. The hypothesis testing procedure uses an analysis of variance (Anava). This test procedure aims to test whether or not there are differences in the effects of several treatments (factors) on the dependent variable.

This research is experimental research with pretest-posttest. The population involved all XI Accounting class students totaling 160 students, while the sample consisted of 64 students who were divided into the experimental class and the control class. The experimental class is a class in the learning process using the Problem-Based Learning model with Peer assessment, while the control class uses the Problem-Based Learning model.

\section{RESULTS AND DISCUSSION}

Prerequisite test results include normality and homogeneity tests. The normality test is used to test whether the sample in the study came from populations that were normally distributed or not. Normality test is used on students' competency data in tax administration subjects using the Problem-Based Learning model with Peer Assessment, and competency data on students in tax administration subjects using the Problem-Based Learning model with student motivation. The results of the normality test are presented in Table 1.

Table 1. Normality Test Data for Student Competency Pretest

\begin{tabular}{ccccccc}
\hline & \multicolumn{3}{c}{ Kolmogorov-Smirnov $^{\text {a }}$} & \multicolumn{3}{c}{ Shapiro-Wilk } \\
\cline { 2 - 6 } & Statistic & df & Sig. & Statistic & df & Sig. \\
\hline Experimental & .132 & 32 & .168 & .946 & 32 & .113 \\
Control & .138 & 32 & .127 & .922 & 32 & .024 \\
\hline
\end{tabular}

Based on Table 1, it can be seen that the significance value for pretest data in the experimental class using the Problem-Based Learning model with Peer Assessment is 0.168 and the control class using the Problem-Based Learning model is 0.127 both of which are greater than the significance level $\alpha$ (alpha) $=0.05$, so it can be concluded that the pretest value data of the experimental class and the control class come from populations that are normally distributed.

Table 2. Normality Test Data for Student Competency Posttest

\begin{tabular}{ccccccc}
\hline & \multicolumn{3}{c}{ Kolmogorov-Smirnov $^{\text {a }}$} & \multicolumn{3}{c}{ Shapiro-Wilk } \\
\cline { 2 - 7 } & Statistic & df & Sig. & Statistic & df & Sig. \\
\hline Experimental & .086 & 32 & $.200^{*}$ & .957 & 32 & .226 \\
Control & .119 & 32 & $.200^{*}$ & .962 & 32 & .309 \\
\hline And
\end{tabular}

Annotation: * This is a lower bound of the true significance

a. Lilliefors Significance Correction 
Based on Table 2, it can be seen that the significance value for the posttest data in the experimental class using the Problem-Based Learning model with Peer Assessment is 0.200 and in the control class using the Problem-Based Learning model is 0.200 both of which are greater than the significance level $\alpha$ (alpha) $=0.05$, so it can be concluded that the posttest value data of the experimental class and the control class come from populations that are normally distributed.

Meanwhile, the homogeneity test is used to determine whether the sample comes from a homogeneous population or not. Homogeneity test uses the F Levene Statistics test. Homogeneity test results are presented in Table 3.

Table 3. Student Competency Homogeneity Test

\begin{tabular}{cccc}
\hline & Pretest & df2 & Sig. \\
\hline Levene Statistic & df1 & 62 & .655 \\
\hline .202 & 1 & & \\
\hline
\end{tabular}

Based on Table 3, in the pretest homogeneity test, it can be seen the value of the statistical levene is 0.222 with a probability value or sig $>0.05$ which is 0.655 then the sample variant is homogeneous. Hypothesis testing is used to answer the research hypotheses that have been conducted. In this study there are three hypotheses: first, there are differences in the effect of the Problem-Based Learning model with Peer Assessment and the Problem-Based Learning model on student competencies, second, there are differences in the effect between students who have high levels of learning motivation and low learning motivation on student competencies, third there is an influence of interaction between the Problem-Based Learning model with Peer Assessment and learning motivation on student competencies. The hypothesis test used in this study is the TwoWay Anova analysis or two-way variance analysis. The results of the analysis is shown in Table 4.

Table 4. Hypothesis Test - Tests of Between-Subjects Effects

\begin{tabular}{cccccc}
\hline \multicolumn{7}{c}{ Dependent Variable: } & Class & & \\
\hline Source & Type III Sum of Squares & df & Mean Square & F & Sig. \\
\hline Corrected Model & $200.625^{\mathrm{a}}$ & 3 & 66.875 & 4.554 & .006 \\
Intercept & 437582.250 & 1 & 437582.250 & 29797.061 & .000 \\
Model & 76.563 & 1 & 76.563 & 5.214 & .026 \\
Error & 881.125 & 60 & 14.685 & & \\
Total & 438664.000 & 64 & & & \\
Corrected Total & 1081.750 & 63 & &
\end{tabular}

Based on the results of data processing using SPSS V.22, Fcount $>$ Ftable or 5.214>2.760 and sig values. $0.026<0.05$, then Ho is rejected and Ha is accepted, stating that there are differences in the influence of the Problem-Based Learning model with Peer Assessment and the Problem-Based Learning model on student competency. There are two types of the hypotheses in this study: the null hypothesis (Ho) and the alternative hypothesis (Ha). Ho states there is no influence or interaction of one variable with other variables, while Ha states that there is an influence or interaction of one variable with another variable. The testing criteria are if the Sig value $<0.05$, then Ho is rejected and $\mathrm{Ha}$ is accepted, while if the Sig value> 0.05, then Ha is rejected.

This study was conducted to determine the effect of the Problem-Based Learning model with Peer Assessment and Problem-Based Learning model on student competencies. This research was conducted in class XI AK 5 by applying the Problem-Based Learning model with Peer Assessment and class XI AK 4 by applying the Problem-Based Learning model. The results of calculations on the first hypothesis obtained data Fcount $>$ Ftable or 5.214> 2.760 and sig value $0.026<0.05$ then Ho is rejected and $\mathrm{Ha}$ is accepted. Based on the data analysis, there are differences in the influence of the Problem-Based Learning model with Peer Assessment and the Problem-Based Learning model on student competency. Besides, learning using the Problem-Based Learning model with Peer Assessment has an average value of 83.78 higher than the average value of the Problem-Based Learning model that is equal to 81.53 . 
The results of this study are consistent with a research by Alias et al. (2015, p. 315) regarding self-assessment, peer assessment, and teacher assessment. The results of the study stated that the results of the pretest and posttest scores of peer evaluations had the highest scores compared to self-assessment and teacher assessment. This is related to two reasons, namely students' reluctance to value others lower than themselves or their belief that others are better than themselves.

With many innovative learning models being used, assessment is an important component that contributes to learning success. Assessment serves to encourage the learning process and provide meaningful feedback for students. Learning as an instructional system refers to a component that depend on each other to achieve the learning objectives.

According to McDonald and Savin-Baden, in learning students are often actively involved in group activities to gain knowledge about the material and problem-solving skills. Thus, in the implementation of Problem-Based Learning, it is important for students to be assessed based on their contribution to group work. Student contributions to group learning in addition to assessments from teachers can be assessed through self-assessment and peer assessment (Alias et al., 2015, p. 310).

Trianto (2012, p. 72) states that the last stage in problem-based learning is evaluation. Evaluations can be done by the teacher, peers, and students themselves. In this study the assessment used is peer assessment, Peer assessment can provide information about themselves and peers who may not be in accordance with what is felt by the teacher (Alias et al., 2015).

Each assessment activity focuses on certain aspects. According to Popham in Budiyono (2011), cognitive aspects of assessment targets focus on students' intellectual operations, affective aspects assessment targets have a focus on attitudes and values of students, and psychomotor aspects of assessment targets have a focus on skills. Thus, the assessment is a procedure for obtaining information about student learning achievement that should be integrated in the learning process in order to support the learning process so as to achieve the learning objectives.

The Problem-Based Learning model with peer assessment can spur students to improve their competence because the use of Problem-Based Learning presents challenges for students to work together in groups, find new information to solve problems, acquire new skills, and be responsible for what they do. When the learning process takes place, students are given the task in the form of problems that must be solved by the group. The problems given are in the form of problems that students must solve to gain knowledge.

The use of Problem-Based Learning can provide free space and thinking processes for students to look for concepts and solve problems related to the material delivered by the teacher. The teacher acts as a facilitator who directs students to be actively involved in the entire learning process by giving problems related to the concepts being learned. Problem-based learning is not designed to help teachers provide as much information as possible to students, but problem-based learning is developed for students to develop thinking skills, problem solving, and intellectual skills.

According to Gielen et al. (2011), there are five general objectives of peer assessment, namely: (1) as a social control tool, (2) as an assessment tool, (3) as a learning tool, (4) as a learning tool for assessing, (5) as an active participation tool. In this study, peer assessment is an assessment tool, where students assess the work of their peers, peer assessment is also a learning tool that is after applying the Problem-Based Learning model and solving problems, students participate in the assessment process. As a learning tool for assessing, students get the right answers along with the steps in the form of rubrics. That way, students who actively participate in learning and can provide feedback on the questions done by their friends, so as to further enhance student understanding.

Asyari et al. (2016) and Downing et al. (2011) in their study concluded that the implementation of Problem-Based Learning encourages students to think critically through planning, debating, raising questions and problems, and analyzing and providing solutions to existing problems in the surrounding environment. In line with a research conducted by Jalani and Sern (2015), the results of the study concluded that Problem-Based Learning improves student test performance during the learning phase. A learning model "Example-Problem Based Learning" provides an example learning strategy and problem solving. Learning through problem solving since students already have knowledge. Thus, this model can improve students' cognitive knowledge. In addition, the results of researches by Sutrisno (2012), Arvianto et al. (2013), and Anggreini et al. (2016) concluded that the application of peer assessment in students' scientific attitudes was effective. 
In contrast to learning that only uses the Problem-Based Learning model without assessment, the application of the Problem-Based Learning model without using assessment also uses group discussion and is given a problem that must be solved by students. Students discuss with each other about the questions given by the teacher, but the assessment is only done by the teacher, and there is a lack of feedback from students because students are not involved in the assessment. The results of the analysis are logical because the model is able to improve students' cognitive competence in calculating Pph article 21.

\section{CONCLUSION}

There are differences in the effect of the application of the Problem-Based Learning model with Peer Assessment and the Problem-Based Learning model on student competency. The Problem-Based Learning model with Peer Assessment is more effective than the Problem-Based Learning model. Students who applied the Problem-Based Learning model with Peer Assessment in learning had an average value of 83.78, higher than the average value of the Problem-Based Learning model of 81.53. The Problem-Based Learning model with Peer Assessment can become teachers' reference in choosing innovative learning models. Through an innovative teaching model, teacher is expected to increase students' learning motivation and active participation to encourage them to improve their competencies and learning objectives can be achieved.

\section{REFERENCES}

Alias, M., Masek, A., \& Salleh, H. H. M. (2015). Self, peer and teacher assessments in problem based learning: Are they in agreements? Procedia - Social and Behavioral Sciences, 204, 309-317. https://doi.org/10.1016/j.sbspro.2015.08.157

Anggreini, D., Kusmayadi, T. A., \& Riyadi, R. (2016). Eksperimentasi model pembelajaran kooperatif tipe Group Investigation (GI) berbasis Assessment for Learning (AfL) melalui penilaian sejawat pada materi Persamaan Garis Lurus ditinjau dari kepercayaan diri siswa terhadap prestasi belajar siswa kelas VIII S. Jurnal Elektronik Pembelajaran Matematika, 4(8), 819-829.

Arvianto, I. R., Mardiyana, M., \& Usodo, B. (2013). Eksperimentasi model pembelajaran kooperatif TGT berbasis Assessment for Learning ditinjau dari gaya kognitif siswa. Jurnal Elektronik Pembelajaran Matematika, 1(7), 672-681.

Asyari, M., Al Muhdhar, M. H. I., Susilo, H., \& Ibrohim, I. (2016). Improving critical thinking skills through the integration of problem based learning and group investigation. International Journal for Lesson and Learning Studies, 5(1), 36-44. https://doi.org/10.1108/ IJLLS-10-2014-0042

Budiyono, B. (2011). Penilaian hasil belajar. Universitas Sebelas Maret Press.

Daryanto, D., \& Rahardjo, M. (2012). Model pembelajaran inovatif. Gava Media.

Djamarah, S. B. (2005). Guru dan anak didik dalam interaksi edukatif. Rineka Cipta.

Downing, K., Ning, F., \& Shin, K. (2011). Impact of problem-based learning on student experience and metacognitive development. Multicultural Education \& Technology Journal, 5(1), 5569. https://doi.org/10.1108/17504971111121928

Gielen, S., Dochy, F., Onghena, P., Struyven, K., \& Smeets, S. (2011). Goals of peer assessment and their associated quality concepts. Studies in Higher Education, 36(6), 719-735. https:// doi.org/10.1080/03075071003759037

Hadie, S. N. H., \& Yusoff, M. S. B. (2016). Assessing the validity of the cognitive load scale in a problem-based learning setting. Journal of Taibah University Medical Sciences, 11(3), 194202. https://doi.org/10.1016/j.jtumed.2016.04.001 
Jalani, N. H., \& Sern, L. C. (2015). Efficiency comparisons between example-problem-based learning and teacher-centered learning in the teaching of Circuit Theory. Procedia - Social and Behavioral Sciences, 204, 153-163. https://doi.org/10.1016/j.sbspro.2015.08.128

Özbıçakçı, Ş., Bilik, Ö., \& İntepeler, Ş. S. (2012). Assessment of goals in problem-based learning. Nurse Education Today, 32(8), 79-82. https://doi.org/10.1016/j.nedt.2012.03.017

Pribadi, B. A. (2011). Model ASSURE untuk mendesain pembelajaran sukses. Dian Rakyat.

Sutrisno, S. (2012). Pembelajaran Fluida menggunakan model Jigsaw dengan Peer Assessment untuk meningkatkan aktivitas, sikap ilmiah, dan prestasi belajar siswa kelas XI IPA. Journal of Innovative Science Education, 1(1), 10-18. https://journal.unnes.ac.id/sju/index.php/jise/ article/view/39

Thomas, G., Martin, D., \& Pleasants, K. (2011). Using self- and peer-assessment to enhance students' future-learning in higher education. Journal of University Teaching \& Learning Practice, 8(1), 1-17. https://ro.uow.edu.au/jutlp/vol8/iss1/5

Trianto, T. (2012). Mendesain model pembelajaran inovatif-progresif. Kencana Prenada Media Group.

Wulandari, B., \& Surjono, H. D. (2013). Pengaruh problem-based learning terhadap hasil belajar ditinjau dari motivasi belajar PLC di SMK. Jurnal Pendidikan Vokasi, 3(2), 178-191. https://doi.org/10.21831/jpv.v3i2.1600

Yew, E. H. J., \& Goh, K. (2016). Problem-based learning: An overview of its process and impact on ILearning. Health Professions Education, 2(2), 75-79. https://doi.org/10.1016/j.hpe. 2016.01.004 